\title{
MUSCLE INVASIVE BLADDER TUMOR 18 MONTHS AFTER LAPAROSCOPIC RADICAL NEPHROURETERECTOMY.
}

\author{
Luis A. Fariña, losu Anton and Daniel Pesqueira.
}

Urology and Pathology. Hospital POVISA. Vigo. Spain.

Summary.- OBJECTIVE: The management of the distal ureter and bladder cuff is an important issue related to laparoscopic nephroureterectomy, because of the fear that local and bladder recurrences could be induced by an inadequate manipulation of the specimen. We present a case of muscle invasive bladder tumor that appeared 18 months after laparoscopic radical nephroureterectomy.
METHODS/RESULTS: A 42 year-old woman with multifocal grade 3 pT3, right kidney urothelial carcinoma, treated by laparoscopic radical nephroureterectomy with early clipping of the distal ureter, transurethral detachment of the intramural ureter, and no bladder closure, presented with an invasive bladder recurrence after 18 months of follow-up.

CONCLUSSIONS: There is no a definitive answer to the question of what is the best and safest way of treating the intramural ureter to prevent local and bladder recurrences. However, early clip occlusion of the ureter to avoid downstream cell seeding during kidney manipulation, and an open approach to the distal ureter in case of concomitant distal ureter or bladder tumor is recommended.

Keywords: Transitional cell carcinoma. Bladder cancer. Kidney cancer. Laparoscopy.

Resumen.- OBJETIVO: El manejo del uréter distal y del manguito vesical es uno de los aspectos más importantes y discutidos de la nefroureterectomía laparoscópica por fumor de urotelio, porque existe el temor de que una manipulación indecuada de la pieza pueda inducir una recidiva vesical o local. Describimos un caso de tumor vesical infiltrante aparecido a los 18 meses de una nefroureterectomía radical laparoscópica.

MÉTODO/RESULTADO: Una mujer de 42 años con carcinoma de urotelio multifocal de la pelvis y cáliz inferior del riñón derecho, grado 3, pT3, que fue tratado mediante desinserción transuretral del uréter intramural y nefroureterectomía radical con clipado precoz del uréter distal, presentó una recidiva de tumor vesical infiltrante a los 18 meses de seguimiento, de curso fatal en poco tiempo. 
CONCLUSIÓN: Aún no hay una respuesta definitiva a la cuestión de cuál es el mejor y más seguro modo de tratar el uréter intramural para prevenir una recidiva local o vesical, después de nefroureterectomia laparoscópica por tumor de urotelio. Se recomienda un oclusión precoz del uréter para evitar una potencial siembra de células durante la manipulación del riñón, y elegir un acceso abierto al uréter distal en caso de tumor de uréter pelviano o de tumor vesical concomitante.

Palabras clave: Carcinoma transicional. Cáncer vesical. Cáncer renal. Laparoscopia.

\section{INTRODUCTION}

Laparoscopic radical nephroureterectomy has reached the condition of standard treatment for the patient with upper urinary tract tumor. Carcinological and survival results are similar to open nephroureterectomy, but perioperative comfort, in-hospital stay and patient recovery are substantially better. The best way to manage the distal ureter and bladder cuff to prevent local and bladder recurrences is one important and much debated issue related to this surgery, because of the fear that local and bladder recurrences could be induced by an inadequate manipulation of the surgical specimen.

\section{CASE REPORT}

A 42 year-old woman with no previous urological disease presented with macroscopic hematuria, and the image study showed an urotelial carcino$\mathrm{ma}$, multifocal in the pelvis and the lower calyx of the right kidney. There were neither bladder or ureteral tumor, nor enlarged regional lymph nodes and kidney function was normal. Urine cytology was positive.

A laparoscopic nephroureterectomy was done, beginning with endoscopic detachment of the intramural ureter aided by an intraureteral catheter, early clipping of the distal ureter once the pneumoperitoneum was established, nephrectomy and specimen retrieval with traction over the distal ureter. The bladder cuff was not closed, and a bladder catheter was placed during eight days.

Anatomopathologic study showed a 5 by $3.5 \mathrm{~cm}$, grade 3 transitional cell carcinoma, invading the renal parenchyma, pT3 (Figure 1), the ureter was normal. There were no metastasis and four cicles of chemotherapy were done (scheme Carboplatine-Gencitabine). On the first urological check-outs, there was not evidence of bladder or retroperitoneal recurrence and urine cytology was normal. After 18 months of follow up, urine cytology was positive and the imaging studies disclosed an invasive recurrence on the right side of the bladder base, demonstrated by endoscopic resection. No enlarged lymph nodes or distant metastasis were found at this moment, so a radical cystectomy and detubularized uretero-sigmoidostomy were done. Histopathology showed a fat-invasive bladder fumor (Figure 2), with vascular, lymphatic and perineural permeation, grade 3, pT3b $\mathrm{pNO}$. Three months after, multiple osseous and thoracic metastases were found, and the patient died six months after radical cystectomy.

\section{COMMENT}

Some three different techniques to remove the intramural ureter in laparoscopic nephroureterectomy are in use. It is possible either a transurethral endoscopic detachment or resection of the intramural ureter, a pure laparoscopic, and an open distal ureter and bladder cuff excision.

Bladder cuff may be kept open, provided that an urethral catheter should rest in place for at least a week, or it may be manually stitched or stapled. Also, timing of distal ureter and kidney manipulation may differ, but early clip or ligature placement on the ureter is recommended, to avoid downstream neoplasic cell seeding during kidney manipulation. Other ways to excise the distal ureter such as cistostomy and intravesical dissection of the ureteral meatus, are minoritary.

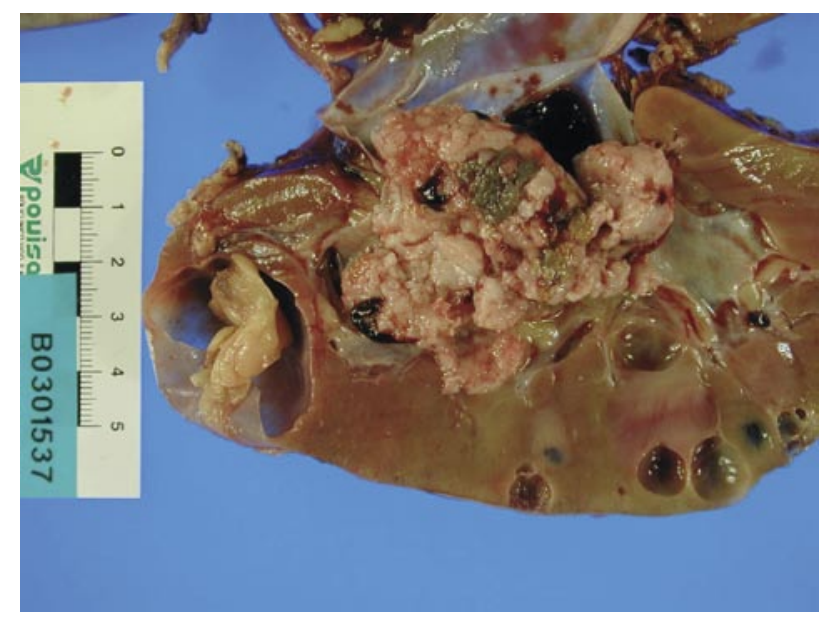

FIGURE 1. Kidney urothelial tumor in the pelvis and lower calyx. 


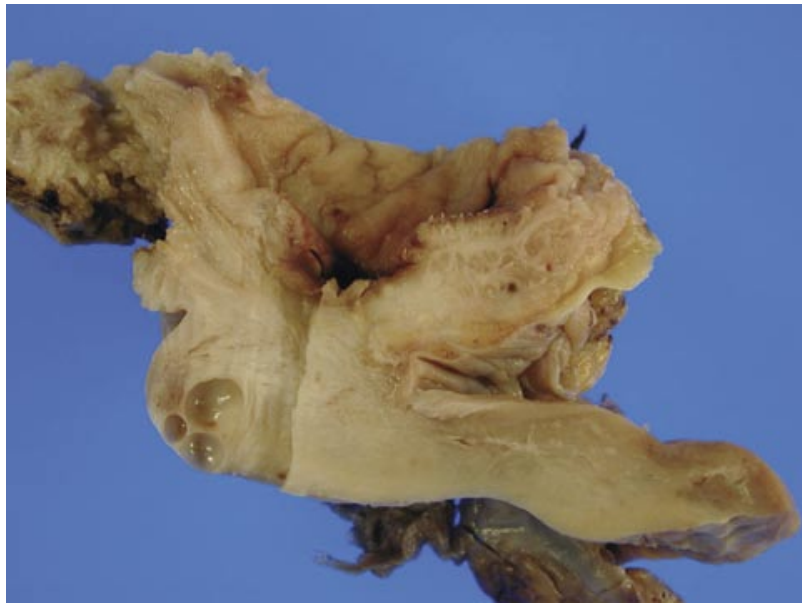

FIGURE 2. Cystectomy specimen. Note infiltrative tumor on the bladder base (uterus below).

The risk of bladder recurrence after endoscopic approach to the distal ureter is 19 to $24 \%$, for a ureteral detachment and excision by way of a transurethral pull-through (stripping technique) or by blunt digital dissection after resection of the ureteral meatus (pluck technique), respectively (1). Recurrences are usually low grade. Only a few cases of muscle invasive bladder tumor have been described after an endoscopic approach to the distal ureter, all of them appeared after a "pluck technique" was practised $(1,2)$.

Recent literature reviews comparing those three different ways of treating the distal ureter and bladder cuff, or comparing the techniques of "bladder cuff open" and "bladder cuff stitched or stapled", did not shown any significant difference in terms of the risk of retroperitoneal or bladder recurrence (3), but we need to analyse those data with the perspective of a longer follow up.

Anyway, early clip occlusion of the ureter to avoid downstream tumor cell seeding during kidney manipulation, a don't-touch-the-tumor-technique, and avoiding contact between the specimen and bladder or abdominal incisions with the use of a proper specimen retrieval bag, are recommended (4). In cases of concomitant ureteral or bladder tumor, an open approach to the distal ureter would be better.

\section{REFERENCES AND RECOMENDED READINGS (*of special interest, ${ }^{* *}$ of outstanding interest)}

**1. LAGUNA, M.P.; DE LA ROSETTE, J.J.: "The endoscopic approach to the distal ureter in nephroureterectomy for upper urinary tract tumor". J. Urol.; 166: 2017, 2001.

*2. ARANGO, O.; BIELSA, A.; CARLES, J. et al.: "Massive tumor implantation in the endoscopic resected area in modified nephroureterectomy". J. Urol.; 157: 1839, 1997.

**3. KURZER, E.; LEVEILLE, R.J.; BIRD, V.G.: "Combining hand-assisted laparoscopic nephroureterectomy with cystoscopic circumferential excision of the distal ureter without primary closure of the bladder cuff -Is it safe?. J. Urol.; 175: 63, 2006.

4. PIECHAUD, T.: "Comment to: Mondet F, Boyer Ch, Esterni J-P. Dissémination métastasique précoce après néphro-urétérectomie pour tumeur de la voie excretrice supérieure: quelle responsabilité de la coelioscopie?". Prog. Urol.; 14 :1203, 2004. 